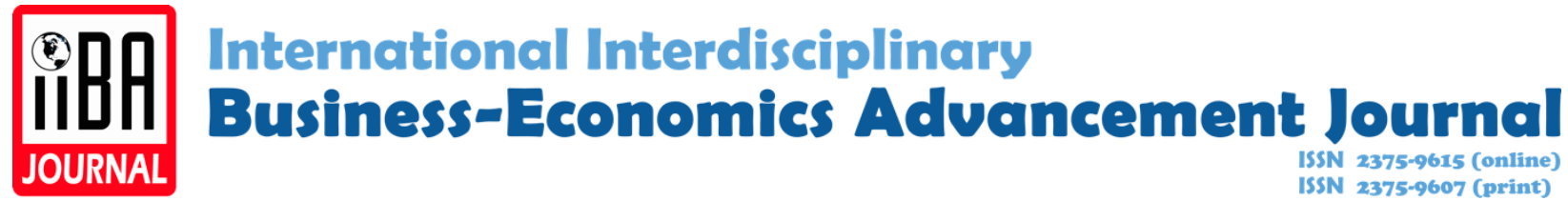

\title{
Family influence, advertising, and R\&D: Implications for firm performance
}

Atanas Nik Nikolov

Washington State University

\section{Recommended Citation}

Nikolov, A. N. (2017). Family influence, advertising, and R\&D: Implications for firm performance. International Interdisciplinary Business-Economics Advancement Journal, 2(2), 65-80.

\section{Revisions}

Submission date: Aug. 2, 2016

1st Revision: Apr. 19, 2017

2nd Revision: May 27, 2017

Acceptance: Jul. 30, 2017 


\title{
Family Influence, Advertising, and R\&D: Implications for Firm Performance
}

\author{
Atanas Nik Nikolov \\ Carson College of Business \\ Washington State University, USA \\ n.nikolov@wsu.edu
}

\begin{abstract}
The literature on family firm performance has failed to conclusively link the impact of family influence on the financial market performance of public firms. The goal of this research is to address this gap by considering mechanisms through which founding family influence contributes to superior firm performance relative to non-family firms. This study links family influence in publicly-traded firms with firm performance in terms of both accounting (Return on Assets) and financial market (Buy-and-Hold-Abnormal-Returns) metrics. The findings support the argument that increased advertising and $R \& D$ focus in family influenced firms reflects a long-term oriented management strategy, consistent with decreased agency costs. Using a large cross-sectional-timeseries sample of publicly traded firms for the period between 2001 and 2010 from 65 different industries, the findings in this article suggest that investments in advertising and R\&D projects have better performance implications in family-owned vs. non-family owned firms. The results are robust to alternative models, measures of firm performance, industry, firm, and time effects.
\end{abstract}

Keywords: family ownership, firm performance, advertising, R\&D

\section{Introduction}

Founding family ownership, (and consecutively family influence) in public firms has been linked to both positive and negative performance consequences in publicly traded firms. Agency theory (Eisenhardt, 1989) suggests that the founding family's continued presence, combined with a large equity ownership position, longer investment horizons, and specialized knowledge of the firm and of product markets, may significantly lower the classic agency problem (Jensen \& Meckling, 1976) between management and owners and thereby boost firm performance in even non-familymajority owned firms (Maury, 2006), through easier monitoring and control over managerial actions (Anderson \& Reeb, 2003; James, 1999; Lee, 2004; Stein, 1988). Conversely, negative performance implications of this ownership structure are equally plausible, as ownership by founding families is often associated with significant disadvantages: inefficient utilization of company resources, extraction of private benefits at the expense of the firm and other shareholder groups, managerial entrenchment and battles for control (Gómez-Mejía, Haynes, Núñez-Nickel, Jacobson, \& Moyano-Fuentes, 2007; Holderness \& Sheehan, 1988; Morck, Stangeland, \& Yeung., 2000; Shleifer \& Vishny, 1997). Consequently, the empirical findings in the literature regarding the implications of family influence on the performance of firms with significant founding family ownership have been inconclusive, despite the plethora of studies purporting to test this linkage. (Carney, Van Essen, Gedajlovic, \& Heugens, 2013; Chrisman, Chua, \& Sharma, 2005; Miller, Le 
Breton-Miller, Lester, \& Cannella, 2007; O’Boyle, Pollack, \& Rutherford, 2012; Villalonga \& Amit, 2006).

The mixed nature of prior empirical research findings, combined with the equally plausible theoretical reasoning behind both the positive and the negative potential impact of family influence on firm performance indicate the presence of contingencies which have not been investigated. For example, with some exceptions (Gallucci, Santulli, \& Calabro, 2015), the mechanisms of the founding family's impact have not been fully investigated to include firm specific strategic investments in value creation and value appropriation activities (Mizik \& Jacobson, 2003) such as R\&D and advertising investments, and how those investments differ in the context of the family influenced firm compared to its non-family competitors. In addition, prior research has highlighted the role of firm strategy in successful family firms as "quite different" from the traditionally more studied non-family firms' strategies (Chrisman et al., 2005; Sharma, Chrisman \& Chua, 1997), providing more theoretical reasoning to study the performance differences of family vs. non-family public firms. Indeed, strategy in family businesses has been woefully understudied (Ibrahim, Angelidis, \& Parsa, 2008; Zahra and Sharma, 2004) and represents a viable area of research.

Investments in $R \& D$ and advertising projects play a key role in stimulating value creation and the subsequent appropriation of the economic benefits for the innovating firm (Mizik \& Jacobson, 2003). In the case of family influenced firms, however, it is likely that such investments may be affected by the different set of agency problems that are characteristic to such entities (Morck \& Yeung, 2003). A chief concern is that management may act in favor of the influential family owners, at the expense of the shareholders in general, and at the extreme, maybe reluctant to invest in R\&D projects and advertising campaigns (Morck et al., 2000). Furthermore, firms that make insufficient investments in R\&D and advertising become less able to exploit market opportunities (McGrath \& Nerkar, 2004) and consequently may suffer low firm performance. However, an alternative argument stipulates that family influence in firms should be associated with higher firm value and performance due to the alignment of the interests of owners and management through the decrease of agency problems in such firms and the encouragement of investments in longerterm oriented R\&D projects to develop new products (Jensen \& Meckling, 1976; Tribo, Berrone, \& Surroca, 2007). Certain marketing investments such as brand building, customer loyalty and satisfaction initiatives also benefit from taking a long-term investment perspective (Srivastava, Shervani, \& Fahey, 1998) and therefore should be affected by family ownership in a similar way as R\&D investments. Therefore, this research investigates the moderating effect of advertising and R\&D spending on the relationship between family firm ownership and performance.

The above arguments are tested using a large sample, multi-industry, multi-time period study context of firms that exhibit family ownership characteristics and represent 53 diverse industries for the period from 2001 to 2010. The findings suggest that family ownership is associated with increased accounting and financial market performance, contingent on increased marketing (advertising) and innovation (R\&D) investments. These results are further bolstered by controlling for other considerations which may also affect firm performance, such as the presence of large institutional shareholders, firm size and leverage. The results are statistically and economically significant and are robust to different modeling methods, endogeneity, multicollinearity, heteroscedasticity, as well as survivorship bias. 
This article makes several contributions to theory and practice. First, it extends the understanding and use of agency theory within the framework of family business research. In doing so, it supports the notion that family ownership represents a viable corporate ownership structure, as it is likely to reduce the classic agency problem (Fama \& Jensen, 1983) between shareholders and management. Second, it adds to the developing debate on the need to identify key strategic considerations which impact the performance of family owned firms (Astrachan, 2010), by showing that the managerial view of $R \& D$ and advertising investments may be a key differentiating factor between family and non-family firms. Finally, this article has implications for the owners and managers of family firms, as the findings suggest that the proper utilization of advertising and R\&D investments might bring about increased accounting and financial market performance, representing a unique resource, which may be deemed a "family ownership premium." Family firms may just be positioned to take better advantage of the same level of investments in R\&D and advertising projects than their non-family owned peers are, due to the reduction of agency costs, and the overall different managerial environment inside the firm.

The remainder of this article consists of a literature review on the relationship between family ownership and firm performance, followed by hypotheses development, methods and results, discussion of findings, limitations, and concluding remarks.

\section{Literature Review}

Overall, family controlled firms are responsible for the creation of the majority of the world's wealth, as these businesses are estimated to contribute between 70-90\% of the world's GDP (Tharawat Magazine, 2014). Furthermore, family owned businesses contribute $57 \%$ of the U.S. GDP, and employ over 63\% of the workforce (Family Enterprise USA, 2011), and are responsible for $78 \%$ of all new job creation (Astrachan \& Shanker, 2003). Founding-family firm ownership represents a common ownership structure that exists in publicly traded companies as well: over 33\% of Fortune 500 firms had equity owned by founding families (Anderson \& Reeb, 2003; Shleifer \& Vishny, 1986). Furthermore, recent studies highlight the widespread nature of this type of corporate structure across the world (Claessens, Djankov, \& Lang, 2000; La Porta, López de Silanes, \& Shleifer, 1999) and claim that this form of corporate equity ownership is at least as common as widely-held and other non-family forms of ownership: For example, Faccio and Lang (2002) document that $44.29 \%$ of the public firms included in their study of Western European economies were family controlled. The importance of founding family ownership in public firms also stems from the fact that family ownership is the prevalent form of corporate ownership in private corporations (over $90 \%$ in most industries), and therefore the residual ownership by the founding families post IPO (initial public offering, i.e. the process via which firms become publically traded) represents further commitment by the company's founders to the future wellbeing of the now public firm (James, 1999). Furthermore, families also have control over almost $20 \%$ of all board seats, and are represented across a broad swathe of industries in the U.S. as well as abroad (Schulze, Lubatkin, \& Dino, 2003).

Despite the widespread existence of fully family owned businesses and businesses with significant residual family ownership, the results in the literature relating such corporate ownership structures with firm performance appear mixed overall. In particular, a large swathe of prior research has investigated contextual factors in the family firm environment such as focusing on family firms in a particular geographic area (Claessens, et al., 2000; King \& Santor, 2008; Silva \& Majluf, 2008), 
control, board representation, and activity of founding family members (Andres, 2008; Lee, 2006; Miller et al., 2007; Minichilli, Corbetta, \& MacMillan, 2010), or the potential of conflicts of interests among family owners and other ownership groups (Anderson \& Reed, 2003).

In terms of the potential benefits of family ownership, prior literature suggests that large, concentrated ownership stakes by founding-families can have certain performance advantages: the unique position that a founding family occupies in the firm makes it easier to influence and monitor management (Demsetz \& Lehn, 1985), thus lowering agency costs (Chrisman, Chua, \& Litz, 2004), and potentially providing a competitive advantage in product and financial markets. The benefits of family ownership occur as the founding family usually has invested most of their private wealth in the company, and therefore have vested interest in the survival of the firm and thus a strong incentive to monitor management closely (Andres, 2008). Furthermore, families may have an advantage in possessing knowledge accumulated over the length of their involvement with the firm about firm and market-specific technologies, essential to better monitoring managerial actions. The long-term nature of family ownership also fosters better ties with internal and external stakeholders such as employees, suppliers, and financial institutions (Anderson \& Reeb, 2003; Ward, 1988), as the family's commitment to the firm is perceived as decreasing the conflicts among the family and non-family shareholders as well as other stakeholders.

The literature on the costs of family ownership is equally well developed. Demsetz and Lehn (1985) and Shleifer and Vishny (1986) suggest that family owners may choose to draw scarce company resources away from potentially profitable projects and seek to extract private benefits from the firm, as the interests of the family are not necessarily in line with those of other shareholders (Fama \& Jensen, 1983). This is due to the entrenchment of family owners, which may incentivize them to exchange profits for private rents and result in the expropriation of other shareholders (Faccio \& Lang, 2002). Furthermore, families may limit the availability of executive management positions to family members (Demsetz \& Lehn, 1985), thus potentially restricting the quality of the labor pool available, leading to competitive disadvantages vis-à-vis non-family industry rivals (Anderson \& Reeb, 2003), and subsequent underperformance in accounting and stock market performance. In some cases, the family members may continue their involvement in the firm even when they are no longer competent (Shleifer \& Vishny, 1997), which may result in one of the largest agency costs which family members can impose on other stakeholders in the firm. In summary, prior literature on the disadvantages of family ownership suggests that ownership costs appear large and significant, as families seek to benefit themselves at the expense of other shareholders, via actions that may lead to suboptimal managerial policies, expropriation, and overall increased agency costs. Taken together, the firm performance implication of substantial family influence in public firms is still an open empirical question.

Considering founding family influence in publicly traded companies through the lens of agency theory suggests that in order to more fully understand the impact of this corporate ownership structure on firm performance, the indirect effects of corporate strategic investments in value creation (R\&D) and value appropriation (advertising) activities (Mizik \& Jacobson, 2003) must be considered, as the mechanism of their impact in family firms may differ. The need to further investigate such firm activities is underscored by the scant attention they have received in family business research (Gallucci et al., 2015; Reuber \& Fischer, 2011), and the differences between family and non-family influenced businesses in the realm of strategic decision making (Moores, 
2009), which makes the former more likely to pursue strategies different from those undertaken in non-family businesses contexts (Kotey, 2005).

R\&D investments drive a firm's technological capabilities, which result in value creation, while its advertising attempts to differentiate its offering from the competition, and thus appropriate as much of the value created for the benefit of the firm as possible (Mizik \& Jacobson, 2003). Investments in $\mathrm{R} \& \mathrm{D}$ generate superior products and process improvements, as the firms attempt to build new solutions and meet customers' needs (Gatignon \& Xuereb, 1997). However, in order to capture at least some of the value it creates, the firm must use various isolating mechanisms in order to differentiate itself from the competition, such as customer loyalty or a strong brand (Aaker, 1996), which can be partially achieved by sustained advertising investments (Bunch \& Smiley, 1992). Indeed, advertising has been attributed with building and sustaining a firm's competitive advantage and market share leadership in product markets (Golder, 2000). Furthermore, communicating the differentiated value added created by product innovation processes (R\&D) yields higher firm value effects of such innovations (Srinivasan \& Hanssens, 2009), and may act as a signal of the firm's financial well-being or competitive viability (Mathur \& Mathur, 2000; Mathur, Mathur, \& Rangan, 1997).

Founding family influence is associated with increased incentives and ability by the family to monitor company management, as large proportion of those families' personal wealth is usually tied to their firm's welfare and they are less diversified than other shareholders (Colli, 2003). Furthermore, as monitoring and control over management may require extensive knowledge about firm operations, technology, and marketing, as well as specialized industry knowledge, families have a good vantage point to provide such oversight, due to their long ownership horizon, permitting the development of such knowledge. The long-term presence of family owners also provides longer investment horizons (Le Breton-Miller \& Miller, 2006) than those of any other shareholder group, supporting the potential for a preference for long-term value generating projects, compared to the more short-term managerial horizons in most public firms (Stein, 1988), or at least decreasing the pressure for achieving short-term performance targets. Further evidence shows that family ownership incentivizes management to undertake more efficient investment projects and may minimize managerial opportunism (Stein, 1999), as the family usually intends to pass on the firm to the next generation (James, 1999) and thus tries to preserve and enhance its value. Overall, agency theorists suggest that family involvement in public firms may decrease agency costs (Chrisman et al., 2004; Jensen \& Meckling, 1976) directly through monitoring activities and indirectly through influencing managerial action in the domain of value creation and appropriation activities via longer investment horizons.

Family firms' value creation and value appropriation decisions may benefit from the extended time horizons of ownership (Le Breton-Miller \& Miller, 2006) and result in an increased firm performance for a number of reasons. First, the long-time horizon of ownership and specialized knowledge that founding families acquire over their tenure with the firm (Anderson \& Reeb, 2003) allow them to better judge which R\&D investments are more likely to result in creating value for customers, and therefore should be pursued, and subsequently supported with the proper investments in value appropriating mechanisms (i.e. advertising) in order to capture some of the value created in the system. Thus, the impact of family ownership monitoring incentives, combined with families' specialized knowledge of the firm and industry, may result in shifting the 
balance between these activities closer to what is optimal for the firm, and should result in an increased performance, compared to non-family firms. Second, sustained benefits from investments in innovation and marketing tend to accrue over the long term (Srinivasan \& Hanssens, 2009) as such activities contribute to building market-based assets (Hunt \& Morgan, 1995; Srivastava et al., 1998) such as strong brands, customer satisfaction, and customer loyalty. Such assets require the leveraging of additional inputs into marketing analysis, such as integrating marketplace and firm knowledge with a clear understanding of the financial consequences of investment decisions. In essence, to achieve positive results from its stock of market-based assets built up through sustained investments into value creation and value appropriation activities, the firm shifts its attention from managing customer exchanges in product markets, to managing such assets, to deliver value for the long-term benefit of its shareholders (Srivastava et al., 1998), including the founding family. In family firms, this shift is likely to occur due to the family's superior knowledge of the firm and industry, combined with its long-term investment horizon (Miller \& Le Breton-Miller, 2006) and monitoring skills, which are likely to result in decreased agency costs. Consequently, the family firm's performance on accounting and stock market performance metrics is likely to be higher than that of non-family firms due to the more efficient and effective use of value generation and value appropriation capabilities to produce and leverage market-based assets.

Therefore, it is likely that investments in value creation (R\&D) and value appropriation (advertising) activities moderate the founding-family ownership - firm performance link:

Hypothesis 1. (A) R\&D and (B) advertising investments positively moderate the relationship between founding family ownership and firm accounting and financial performance (ROA and BHAR).

Figure1 provides a visual representation of the research model.

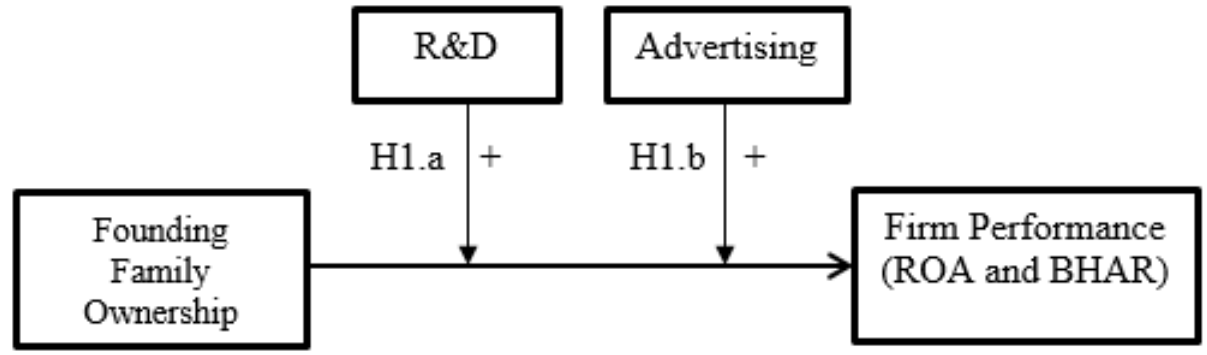

Figure 1: Conceptual model

\section{Methods}

This section presents the methods used to test the hypotheses. The main hypotheses are tested using two different quantitative methods, with data on companies listed on U.S. stock exchanges. The dataset is structured as a panel (i.e. cross-sectional time-series longitudinal data for the period 2001-2010).

\section{Data Collection and Sample}

Following Anderson, Duru and Reeb (2009) and Anderson, Reeb and Zhao (2012) the data sample is constructed as follows; First, family ownership data for all firms in COMPUSTAT with 
available data for the period between 2001 and 2010 and excluding regulated utilities, financial firms, foreign firms, master limited partnerships, and firms with share prices of less than $\$ 0.25$ is obtained. Second, the sample is restricted to the 2,000 largest firms based on total assets for datayear 2001. Next, an established and previously validated framework for measuring family ownership (Anderson \& Reeb, 2003) is utilized to compute the fractional equity ownership of the founding family and to identify family firms. The data is available through corporate histories (Gale Business Resources, Hoovers, and individual corporate websites), as well as through SEC $10-\mathrm{K}$ company filings. Following prior research, an indicator variable equal to 1 is used if the family holds or votes a 5\% or larger ownership stake in the company (Anderson et al., 2009). This measure is more suitable than the raw ownership percentage of family holdings, as the differences in ownership levels among family firms may not represent the actual influence a particular family may have on the firm (i.e. an equity stake of $2 \%$ may have a larger impact than one of $12 \%$, depending on the ownership control structure and share classes). To control for potential survivorship bias in the data, firms are allowed to exit and re-enter the sample during each period. Following these procedures, the family ownership data is merged with data for all other variables of interest in the study, resulting in 9,995 firm-year observations for both family and non-family firms.

Of the total 2000 firms in the sample, there are 464 unique family firms, which are on average slightly older than non-family firms ( 9 years compared to 8 years since going public), and are present in 53 of the 65 industries in the dataset based on two-digit SIC codes. The top five industries in which such firms operated were business services (SIC code 73), apparel and accessory stores (SIC code 56), food and kindred products manufacturing (SIC code 20), communications (SIC code 48), and chemical and allied products manufacturing (SIC code 28), and all of their headquarters were located in the U.S. The data for all additional variables comes from the COMPUSTAT and CRSP databases. Table 1 lists all variables, their correlations, and descriptive statistics.

\section{Variables}

Firm performance is measured by using accounting return on assets (ROA) (Arosa, Iturralde, \& Maseda, 2010) and Buy-and-Hold-Abnormal-Returns (BHAR). These two dependent variables are suitable to the context under investigation, as the focus of the paper is on family-owned firms which are also publicly traded, thus the impact of family involvement is likely to be captured in both accounting (ROA) and stock market measures of performance (BHAR). ROA is computed as earnings before interest, tax, depreciation, and amortization (EBITDA) divided by the book value of total assets. To estimate the second measure of firm performance, buy and hold abnormal returns (Daniel \& Titman, 1997) are calculated; this model compares the actual returns of a portfolio of firms with those of a hypothetical benchmark portfolio of stocks that belong to the same size, bookto-market, and momentum quintiles as the stock of the firm under investigation. Specifically, BHAR is computed using the following method:

BHAR $_{i, t}=\prod\left(1+R_{i, m, t}\right)-\Pi\left(1+R_{j(i, m, t)}\right)$

where $t$ is the fiscal year; $m$ is the month within each year; $R i, m, t$ is the return of the specific firm $\mathrm{i}$ in month $\mathrm{m}$ of year $\mathrm{t}$; and $\mathrm{R} \mathrm{j}(\mathrm{i}, \mathrm{m}, \mathrm{t})$ is the return of the control portfolio $\mathrm{j}$ which includes all stocks of the same size, book-to-market, and momentum quintiles as firm $\mathrm{i}$ at the beginning of month $\mathrm{m}$ 
of year t. In essence, the buy and hold returns approach reflects the abnormal return that an investor would be able to earn from holding a stock for an extended period, using compounded interest, and is therefore preferred for studies which require testing firm performance over longer time horizons (Barber \& Lyon, 1997), which is likely to be the case with family owned firms, especially when the impact of strategic actions needs to be taken into account.

The main independent variables of interest are family ownership in publicly traded firms, advertising and R\&D investments. Advertising and R\&D investments are two of the main corporate level strategies used in all businesses to generate and appropriate value. Advertising investment is measured as intensity: the amount spent on advertising in a given year, divided by the book value of firm total assets, in order to control for firm size effects, as larger companies tend to advertise more. $R \& D$ investment is measured in a similar manner: R\&D spending scaled by the book value of firm total assets, based on data from the COMPUSTAT annual data file.

Controls are implemented for firm size, measured as the natural logarithm of the total firm assets (Olson et al., 2003), level of financial leverage of the firm, as the debt to equity ratio (Cheng, 2009), and ownership by other large outside institutional investors (holding at least 5\% equity stake in a company in a given year), as those organizations may have an outsize influence over managerial decision making through monitoring and disciplining actions Schleifer and Vishny (1997), in addition to, or over and above, the effects of founding family ownership, which may mask the true nature of family involvement in publicly traded firms, when such entities are present in the ownership structure. To test the moderating effects of advertising and R\&D investments, the interaction variables are calculated as the products of the independent variables, resulting in two different moderators: (founding family ownership) $\times$ (advertising investment), and (founding family ownership $) \times(R \& D$ investment $)$.

Table 1: Descriptive Statistics and Correlation Matrix

\begin{tabular}{|c|c|c|c|c|c|c|c|c|c|c|}
\hline Variable & Mean & $\begin{array}{l}\text { St. } \\
\text { Dev }\end{array}$ & ROA & BHAR & $\begin{array}{l}\text { Family } \\
\text { Firm } \\
\end{array}$ & ADVG & R\&D & Size & Leverage & $\begin{array}{l}\text { Inst. } \\
\text { Own }\end{array}$ \\
\hline $\mathrm{ROA}$ & .1058 & .45 & 1 & & & & & & & \\
\hline BHAR & -.1198 & .63 & .0096 & 1 & & & & & & \\
\hline Family Firm & .2914 & .45 & .0117 & .0138 & 1 & & & & & \\
\hline Advertising & .0116 & .04 & .0172 & -.0121 & .0634 & 1 & & & & \\
\hline $\mathrm{R} \& \mathrm{D}$ & .0313 & .18 & -.7592 & .0035 & -.1148 & .0043 & 1 & & & \\
\hline Size & 6.8716 & 2.25 & .0738 & .0062 & -.1422 & -.0945 & -.1797 & 1 & & \\
\hline Leverage & .5075 & .42 & -.0085 & -.0755 & -.0309 & -.0421 & -.0498 & .1024 & 1 & \\
\hline $\begin{array}{l}\text { Institutional } \\
\text { ownership }\end{array}$ & .3844 & .36 & .0483 & .0496 & -.1380 & -.0140 & -.0299 & .2717 & -0.3140 & 1 \\
\hline
\end{tabular}

Note: Entries in bold indicate significant correlation coefficients

The impact of marketing and innovation investments on the relationship between founding family influence and the two measures of firm performance (ROA) and (BHAR) is modeled by implementing a moderated multiple regression (Aguinis, Gottfredson, \& Wright, 2011) using panel data, with fixed effects and controls for time and industry effects. The use of cross-sectional fixed effects is desirable in this setting, as it relaxes the strict exogeneity assumption for the regressors and is preferable to other methods (Cameron \& Trivedi, 2009), as the main independent variables and controls are not time-invariant (Wooldridge, 2010). 
$R O A_{i, t}=\beta_{0}+\beta_{1}$ FamilyFirm $_{i, t}+\beta_{2} X A D_{i, t}+\beta_{3} R N D_{i, t}+\beta_{4}$ FamilyFirm $_{i, t} \times X A D_{i, t}+$

$\beta_{5}$ FamilyFirm $_{i, t} \times R N D_{i, t}+\beta_{6} I N S T_{i, t}+\beta_{7} L E V_{i, t}+\beta_{8} S I Z E_{i, t}+u_{i}+e_{i, t}$,

where $\mathrm{ROA}_{\mathrm{i}, \mathrm{t}}=$ Return on Assets for firm $\mathrm{i}$ at time $\mathrm{t}$,

FamilyFirm ${ }_{i, t}=$ dummy variable equal to 1 if firm $i$ at time $t$ is a family firm,

$\mathrm{XAD}_{\mathrm{i}, \mathrm{t}}=$ Advertising intensity for firm $\mathrm{i}$ at time $\mathrm{t}$,

$\mathrm{RND}_{\mathrm{i}, \mathrm{t}}=\mathrm{R} \& \mathrm{D}$ intensity for firm $\mathrm{i}$ at time $\mathrm{t}$

$\mathrm{INST}_{\mathrm{i}, \mathrm{t}}=$ All institutional holdings (percentage) in firm $\mathrm{i}$ at time $\mathrm{t}$,

$\mathrm{LEV}_{\mathrm{i}, \mathrm{t}}=$ Degree of indebtedness (leverage ratio) of firm $\mathrm{i}$ at time $\mathrm{t}$,

SIZE $_{\mathrm{i}, \mathrm{t}}=$ size of firm $\mathrm{i}$ at time $\mathrm{t}$, measured as the $\log$ of firm assets.

The same modeling approach is used to estimate the regression for the stock market return variable of interest (BHAR), substituting BHARi,t for ROAi,t in equation (2). Furthermore, all independent variables are mean-centered in order to test the moderating effects and to avoid collinearity issues (Aguinis et al., 2011; Aiken, West, \& Reno, 1991). Next, the two separate regression models for each dependent variable are tested in turn: first testing only the main effects of the explanatory and control variables (Model 1), and second, the explanatory variables, controls, and interaction terms (Model 2).

It is possible that there are endogeneity concerns in the context of publicly traded firms with family ownership as their performance may lead to higher investments in advertising and R\&D activities compared to non-family firms, resulting in reverse causality (i.e. firm performance leading to increased advertising and R\&D investments). In order to address some of those concerns and to check for the robustness of the results from the model in equation (2), the Blundell-Bond system generalized method of moments (GMM) approach is used (Blundell \& Bond, 1998); this approach has been employed by prior studies when external instrumental variables were not a feasible option (e.g., Rego, Morgan, \& Fornell, 2013; Yoganarasimhan, 2012).

The system GMM approach increases efficiency over the other GMM approaches, such as the more popular Arellano-Bond only estimator (Arellano \& Bond, 1991), by introducing additional internal instruments. Variables in levels are instrumented with lags of their own first differences, and the only assumption needed is that these differences are uncorrelated with the unobserved firm effects (Blundell \& Bond, 1998). This estimation approach is suitable for situations in which independent variables (family ownership, advertising, and R\&D investments) are not strictly exogenous (i.e. uncorrelated with past and possibly current realizations of the error term), as well as when there is potential for autocorrelation and heteroscedasticity within firms (Roodman, 2006).

\section{Findings}

The results from the analyses, performed using STATA 14.0 are presented in this section. Table 1 shows the descriptive statistics and correlations among the variables and show bivariate correlations. Overall, it shows relatively low levels of correlation among independent variables and the dependent variables. Next, table 2 presents model-free evidence which supports the mixed findings of previous empirical research regarding the direct effects of family firm ownership on firm performance: In all but 4 of the sample years, the performance differences in terms of return on assets between family and non-family firms were not different from zero (i.e. not statistically 
significant). However, in the four years which exhibit significant differences between those two types of firms, it appears that family firms performed marginally better on average.

Table 2: Average Firm Performance (ROA) of Family vs. Non-Family Firms, t-Tests

\begin{tabular}{lllllllllll}
\hline Year & $\mathbf{2 0 0 1}$ & $\mathbf{2 0 0 2}$ & $\mathbf{2 0 0 3}$ & $\mathbf{2 0 0 4}$ & $\mathbf{2 0 0 5}$ & $\mathbf{2 0 0 6}$ & $\mathbf{2 0 0 7}$ & $\mathbf{2 0 0 8}$ & $\mathbf{2 0 0 9}$ & $\mathbf{2 0 1 0}$ \\
\hline Non-family & & & & & & & & & & \\
firm & .1226 & .1175 & .1205 & .1289 & .1373 & .1396 & .1321 & .1342 & .1197 & .1355 \\
Family firm & $\mathbf{. 1 3 3 8}$ & $\mathbf{. 1 2 6 1}$ & $\mathbf{. 1 2 8 8}$ & $\mathbf{. 1 4 0 1}$ & .1431 & .1392 & .1311 & .122 & .1073 & .1363 \\
t-test p-value & $.05^{\mathrm{a}}$ & $.09^{\mathrm{a}}$ & $.07^{\mathrm{a}}$ & $.03^{5}$ & .17 & .51 & .55 & .89 & .93 & .46 \\
\hline
\end{tabular}

Note: ${ }^{\text {a }}$ Significant at the .10 level (2-tailed); ${ }^{\mathbf{b}}$ Significant at the .05 level (2-tailed)

Next, the left panel of table 3 lists the results from equation (2) for the accounting performance variable of interest (ROA). The findings suggest that there is no direct effect of founding ownership on firm performance on either (ROA) or (BHAR), consistent with prior research. However, the results from the moderation analysis suggest that increasing advertising intensity relates to increased accounting performance $\left(\beta_{4}=.3808\right.$, $\mathrm{p}$-value $\left.<.01\right)$. Furthermore, this is also the case for increasing $R \& D$ spending $\left(\beta_{5}=.00001, p\right.$-value $\left.<.01\right)$. Therefore, there is support for the beneficial impact of family ownership structure on the payoffs to advertising and $R \& D$ investments for accounting performance (ROA), supporting H1.a and H1.b.

Table 3: Impact of Family Ownership, Advertising and R\&D, Panel Data Fixed Effects Regressions

\begin{tabular}{lllll}
\hline & ROA & & BHAR & \\
\hline Variable & Model 1 & Model 2 & Model 1 & Model 2 \\
\hline Family Firm & .0032 & .0039 & .0387 & .0417 \\
Advertising & $.2719 * * *$ & $.2940 * * *$ & $-1.6752 * *$ & $-1.6057 * * *$ \\
R\&D & $-.6867 * * *$ & $-.6888^{* * *}$ & $-.7310 * *$ & $-.7256^{* *}$ \\
Family Firm $\times$ Advertising & & $\mathbf{3 8 0 8 * * *}$ & & $\mathbf{1 . 6 4 2 4} * * *$ \\
Family Firm $\times$ R\&D & & $\mathbf{. 0 0 0 0 1} * * *$ & & .00001 \\
Institutional Ownership & $.0151 * *$ & $.0156 * * *$ & -.0483 & -.0467 \\
Leverage & $-.1075 * * *$ & $-.1076 * * *$ & $-.3167 * * *$ & $-.3170 * * *$ \\
Firm Size & $-.0032^{*}$ & $-.0033 *$ & $-.0869 * * *$ & $-.0869 * * *$ \\
Number of Observations & 9,983 & 9,983 & 9,745 & 9,745 \\
Time Fixed Effects & YES & YES & YES & YES \\
Industry Fixed Effects & YES & YES & YES & YES \\
\hline
\end{tabular}

Note: No-Bond GMM Results: Effects of S DIMENSIONS AND EXAMPLESPRODU* $\mathrm{p}<.10 . * * \mathrm{p}<.05$. *** $\mathrm{p}$ $<.01$.

The right panel of table 3 presents the results for the stock market performance variable of interest (BHAR). The results are largely consistent with those for accounting performance: increasing advertising intensity in family firms is associated with increased firm performance (BHAR) $\left(\beta_{4}=\right.$ 1.6424 , p-value $<.01)$. The results for $\mathrm{R} \& \mathrm{D}$ investments do not approach statistical significance in this case, however, thus supporting only H1.b for the stock market firm performance measure. In both cases, the findings support the notion of the positive impact of family ownership when firms decide to increase their emphasis on value appropriation activities through advertising.

Table 4 presents the results from the first robustness check, using the alternative Blundell-Bond system GMM regression model. Using this alternative model, the findings suggest a negative main effect of family ownership on firm performance in terms of (ROA) $\left(\beta_{1}=-.0376\right.$, p-value $\left.<.01\right)$, however, this effect reverses when using a stock market measure of performance (BHAR) $\left(\beta_{1}=\right.$ 
.3374 , p-value $<.01$ ), further confirming the mixed nature of results in the empirical literature (Astrachan, 2010).

The left panel further presents the results for the return on assets (ROA) model. The findings from the moderation analysis suggest that increasing advertising intensity in family influenced firms is associated with increased accounting performance $\left(\beta_{4}=.7051\right.$, $p$-value $\left.<.01\right)$. Furthermore, this is also the case for increasing $R \& D$ intensity $\left(\beta_{5}=.0002\right.$, p-value $\left.<.01\right)$.

Table 4: Impact of Family Ownership, Advertising and R\&D, Blundell-Bond System GMM Model

\begin{tabular}{|c|c|c|c|c|}
\hline & ROA & & BHAR & \\
\hline Variable & Main Model & Full Model & Main Model & Full Model \\
\hline Family Firm & $-.0376 * * *$ & $-.0281 * * *$ & $.3374 * * *$ & $.3914 * * *$ \\
\hline Advertising & $.1451 * * *$ & $.1727 * * *$ & -.8870 & -.4310 \\
\hline $\mathrm{R} \& \mathrm{D}$ & $-.8647 * * *$ & $-.9128 * * *$ & $-.8006 * *$ & $-.9900 * * *$ \\
\hline Family Firm $\times$ Advertising & & $.7051 * * *$ & & $7.0452 * *$ \\
\hline Family Firm $\times$ R\&D & & $.0002 * * *$ & & $.0008 *$ \\
\hline Institutional Ownership & $-.0252 * * *$ & $-.0232 * * *$ & .0164 & .0190 \\
\hline Leverage & $-.2457 * * *$ & $-.2429 * * *$ & $.1361 *$ & $.2032 * * *$ \\
\hline Firm Size & $.0083 * * *$ & $.0033 * * *$ & $-.1919 * *$ & $-.2352 * * *$ \\
\hline Number of Observations & 8,188 & 8,188 & 8,026 & 8,026 \\
\hline
\end{tabular}

Notes: No-Bond GMM Results:Effects of S DIMENSIONS AND EXAMPLESPRODU*** $\mathrm{p}<.01, * * \mathrm{p}<.05, * \mathrm{p}$ $<.10$.

The right panel of table 4 presents the results for the stock market performance variable of interest (BHAR). The results are consistent with those for accounting performance: family firms seem to tolerate higher advertising investments than non-family firms, which benefit their stock market performance $\left(\beta_{4}=7.0452\right.$, p-value $\left.<.05\right)$. Furthermore, this is also the case for increasing $R \& D$ spending $\left(\beta_{5}=.0008, \mathrm{p}\right.$-value $\left.<.10\right)$. Therefore, the Blundell-Bond System GMM analysis provides additional support for the beneficial impact of family ownership structure on the payoffs to advertising and R\&D investments fully supporting both H1.a and H1b.

\section{Conclusions}

This research attempts to investigate (1) whether family influence in publicly traded firms is associated with increased firm performance, and (2) whether increasing investments in value creation (R\&D) and value appropriation (advertising) activities moderate the relationship. The main findings suggest that overall family ownership has no impact on two measures of firm performance (ROA and BHAR) as a main effect. In a robustness check, using a different methodological approach, the impact of family ownership appears mixed: negative for accounting performance, and positive for stock market performance. These results confirm prior evidence suggesting mixed findings in the empirical literature in family business research linking this ownership structure with firm performance (Astrachan, 2010).

However, family firms which also emphasize investments in value-creating and valueappropriating activities such as R\&D and advertising have higher return on assets (ROA) and stock market performance (BHARs) than their non-family competitors. This second set of findings suggests that family influence in public firms is associated with higher firm performance vis-à-vis non-family firms, even after the family owners have diluted their ownership stake after the IPO 
stage, however, only when these firms invest in R\&D and advertising activities. The increase in ROA is likely linked to the growth of earnings, as family firms seem to be able to utilize advertising and R\&D investments more efficiently on a dollar for dollar basis, compared to non-family owned firms. This is because family firms which focus on such isolating mechanisms are likely benefiting from the long-time horizon of ownership of the family (Miller \& Le-Breton-Miller, 2006) which has been associated with a willingness to commit resources toward the ultimate success of the business (James, 1999; Laverty, 1996). Long horizon oriented investments are a necessary condition for the development of market-based assets (Srivastava et al., 1998) such as strong brands, customer loyalty, and customer satisfaction, which in turn are associated with sustainable increases in firm performance over the long-term, and thus represent one of the key differentiating factors between family and non-family firms.

The findings are further strengthened by the large sample size and the longitudinal nature of the data, the control for survivorship bias, as well as the 53 distinct industries featuring family firms included in the study, which allows for context-free generalization of the results. Furthermore, the study context allows for using different dependent variables, and underscores the importance of investigating multiple performance measures in studying family businesses, as one of the shortcomings of prior research has been determining the suitability of performance metrics (Astrachan, 2010) in family business research.

Through the lens of agency theory (Eisenhardt, 1989) these findings support the assertion that the reduction in agency costs attributed to founding family ownership in public firms is beneficial to increased firm performance, as it allows for better monitoring of management by influential family owners, interested in the long-term survival and viability of the firm. However, the reduction in agency costs appears a necessary, but not sufficient condition for increased performance to occur: this study supports the notion that that the reduction in agency costs is beneficial only when combined with an environment conducive to fostering long-term investments in value generation and value appropriation activities, which in turn seem to differentiate the family firm from nonfamily competitors and act as an isolating mechanism, contributing to accounting and stock market outperformance. Moreover, the findings support the mechanisms through which family involvement manifests in increased firm performance, and uncover one of the possible strategic reasons for the existence of a de-facto family ownership premium in U.S. publicly traded firms with residual family ownership.

The findings suggest that increasing R\&D and advertising investments in the context of family firms act as a long-term, sustained corporate strategic policy and have positive implications for firm performance, and therefore offer compelling suggestions for executives, managers, investors and other stakeholders of such firms. First, managers of family influenced firms should be able to better support their R\&D and advertising budgeting requests for investments in projects with longer-term payoff projections. Due to the unique corporate structure, and the decrease in agency costs in family firms, management is positioned to take advantage of such investments, as the family ownership may offer a degree of protection from pressures for short-term performance by outside factors. Second, upper level management and executives may benefit by utilizing the findings in this research to decrease outside pressures on their firms for short-term performance at the expense of sacrificing long-term value creating investments in $R \& D$ and certain advertising initiatives (i.e. investing in brand building, customer satisfaction and loyalty campaigns). This 
effect could be accomplished by emphasizing the benefits of the family's influence in the firm: the deep knowledge of the firm and the industry overall, coupled with the increased monitoring of management may prevent myopic decisions in the domain of value creation and value appropriation in the domain of strategy setting and execution. Third, investors in family influenced public firms may also benefit by adopting a longer-term perspective on their holdings of advertising and R\&D intensive family firms. In essence, their return on investment should increase due to the family ownership premium identified in this research, as such longer-term investment perspective matches with the time horizon of strategic managerial decisions taken inside the family firm.

Previous studies have suggested that founding family ownership as a corporate structure is plagued with issues of nepotism, entrenchment, and exploitation of minority shareholders which ultimately would lead to lower performance (Miller et al., 2007) as it imposes a relatively high agency cost on other shareholders. Contrary to such previous findings, the current set of results suggests that founding family ownership represents a positive influence on public firms on average; the role of the founding family as an influential stockholder emerges as a monitoring and control mechanism which can influence managerial decision making by encouraging a long-term orientation, which is in turn conducive to fostering long-term growth oriented investments, resulting in increasing firm performance. However, the results do not suggest that family influence leads directly to higher investments in R\&D and advertising activities, as this study did not conduct a mediation analysis; therefore, this is one of the limitations of the current research. Yet, there is some prior evidence to suggest that family firms tend to be associated with higher investments in R\&D than non-family firms (Weber, Lavelle, Lowry, Zellner, \& Barrett, 2003), which may provide some support for this argument and buttress the research findings in the current study.

Other limitations (and opportunities for further research) stem from discovering the exact mechanisms via which founding family ownership influences marketing and innovation investments and strategies. Furthermore, investigating this study's implications in the context of non-publicly traded family firms and in international contexts would add additional insight to our understanding of whether the mechanisms supporting value creation and value appropriation are similar, as this study relies on data for relatively large, publicly listed firms on U.S. stock exchanges. Such businesses may differ significantly from non-exchange listed family firms, and thus may impact the nature of the payoffs to advertising and R\&D investments. Therefore, some additional future research directions would be to investigate the treatment of these strategic investments under various family-ownership scenarios such as studying their implications for long-term survival of the firm, building competitive capabilities, internationalization, family succession and family dynamics issues, and changes in ownership or control.

\section{References}

Aaker, D. A. (1996). Measuring brand equity across products and markets. California Management Review, 38(3), 103.

Aguinis, H., Gottfredson, R. K., \& Wright, T. A. (2011). Best-practice recommendations for estimating interaction effects using meta-analysis. Journal of Organizational Behavior, 32(8), 1033-1043.

Aiken, L. S., West, S. G., \& Reno, R. R. (1991). Multiple regression: Testing and interpreting interactions. Thousand Oaks, CA: Sage.

Anderson, R. C., Duru, A., \& Reeb, D. M. (2009). Founders, heirs, and corporate opacity in the United States. Journal of Financial Economics, 92(2), 205-222. 
Anderson, R. C., Reeb, D. M. (2003). Founding-family ownership and firm performance: Evidence from the S\&P 500. The Journal of Finance, 58(3), 1301-1327.

Anderson, R. C., Reeb, D. M., \& Zhao, W. (2012). Family-controlled firms and informed trading: Evidence from short sales. The Journal of Finance, 67(1), 351-385.

Andres, C. (2008). Large shareholders and firm performance-An empirical examination of founding-family ownership. Journal of Corporate Finance, 14(4), 431-445.

Arellano, M., \& Bond, S. (1991). Some tests of specification for panel data. The Review of Economic Studies, 58(2), 277-97.

Arosa, B., Iturralde, T., \& Maseda, A. (2010). Ownership structure and firm performance in non-listed firms: Evidence from Spain. Journal of Family Business Strategy, 1(2), 88-96.

Astrachan, J. H. (2010). Strategy in family business: Toward a multidimensional research agenda. Journal of Family Business Strategy, 1(1), 6-14.

Astrachan, J. H., \& Shanker, M. C. (2003). Family businesses' contribution to the US economy: A closer look. Family Business Review, 16(3), 211-219.

Barber, B. M., \& Lyon, J. D. (1997). Detecting long-run abnormal stock returns: The empirical power and specification of test statistics. Journal of Financial Economics, 43(3), 341-372.

Blundell, R., \& Bond, S. (1998). Initial conditions and moment restrictions in dynamic panel data models. Journal of Econometrics, 87(1), 115-143.

Bunch, D. S., \& Smiley, R. (1992). Who deters entry? Evidence on the use of strategic entry deterrents. The Review of Economics and Statistics, 74(3), 509-521.

Cameron, A. C., \& Trivedi, P. K. (2009). Microeconometrics using stata (Vol. 5). College Station, TX: Stata.

Carney, M., Van Essen, M., Gedajlovic, E. R., \& Heugens, P. P. (2013). What do we know about private family firms? A meta-analytical review. Entrepreneurship Theory and Practice, 39(3)5, 13-544.

Cheng, M. T. (2009). Relative effects of debt and equity on corporate operating performance: A quantile regression study. International Journal of Management, 26(1), 142.

Chrisman, J. J., Chua, J. H., \& Litz, R. A. (2004). Comparing the agency costs of family and non-family firms: Conceptual issues and exploratory evidence. Entrepreneurship Theory and Practice, 28(4), 335-354.

Chrisman, J. J., Chua, J. H., \& Sharma, P. (2005). Trends and directions in the development of a strategic management theory of the family firm. Entrepreneurship Theory and Practice, 29(5), 555-576.

Claessens, S., Djankov, S., \& Lang, L. H. (2000). The separation of ownership and control in East Asian corporations. Journal of Financial Economics, 58(1), 81-112.

Colli, A. (2003). The history of family business, 1850-2000 (Vol. 47). Cambridge, MA: Cambridge University.

Daniel, K., \& Titman, S. (1997). Evidence on the characteristics of cross sectional variation in stock returns. The Journal of Finance, 52(1), 1-33.

Demsetz, H., \& Lehn, K. (1985). The structure of corporate ownership: Causes and consequences. The Journal of Political Economy, 93(6), 1155-1177.

Eisenhardt, K. M. (1989). Agency theory: An assessment and review. Academy of Management Review, 14(1), 5774.

Faccio, M., \& Lang, L. H. (2002). The ultimate ownership of Western European corporations. Journal of Financial Economics, 65(3), 365-395.

Fama, E. F., \& Jensen, M. C. (1983). Separation of ownership and control. Journal of Law and Economics, 26(2), 301-325.

Family Enterprise USA. (2011). Annual family business survey: General results \& conclusions. Retrieved from https://www.uvm.edu/business/vfbi/documents/2011_Annual_Family_Business.pdf.

Gallucci, C., Santulli, R., \& Calabrò, A. (2015). Does family involvement foster or hinder firm performance? The missing role of family-based branding strategies. Journal of Family Business Strategy, 6(3), 155-165.

Gatignon, H., \& Xuereb, J. M. (1997). Strategic orientation of the firm and new product performance. Journal of Marketing Research, 34(1), 77-90.

Golder, P. N. (2000). Historical method in marketing research with new evidence on long-term market share stability. Journal of Marketing Research, 37(2), 156-172.

Gómez-Mejía, L. R., Haynes, K. T., Núñez-Nickel, M., Jacobson, K. J., \& Moyano-Fuentes, J. (2007). Socioemotional wealth and business risks in family-controlled firms: Evidence from Spanish olive oil mills. Administrative Science Quarterly, 52(1), 106-137.

Holderness, C. G., \& Sheehan, D. P. (1988). The role of majority shareholders in publicly held corporations: An exploratory analysis. Journal of Financial Economics, 20, 317-346.

Hunt, S. D., \& Morgan, R. M. (1995). The comparative advantage theory of competition. The Journal of Marketing, 59(2), 1-15. 
Ibrahim, N. A., Angelidis, J. P., \& Parsa, F. (2008). Strategic management of family businesses: Current findings and directions for future research. International Journal of Management, 25, 95-110.

James, H. S. (1999). Owner as manager, extended horizons and the family firm. International Journal of the Economics of Business, 6(1), 41-55.

Jensen, M. C., \& Meckling, W. H. (1976). Theory of the firm: Managerial behavior, agency costs and ownership structure. Journal of Financial Economics, 3(4), 305-360.

King, M. R., \& Santor, E. (2008). Family values: Ownership structure, performance and capital structure of Canadian firms. Journal of Banking \& Finance, 32(11), 2423-2432.

Kotey, B. (2005). Goals, management practices, and performance of family SMEs. International Journal of Entrepreneurial Behavior \& Research, 11(1), 3-24.

La Porta, R., Lopez-de-Silanes, F., Shleifer, A., \& Vishny, R. (1999). The quality of government. Journal of Law, Economics, and Organization, 15(1), 222-279.

Laverty, K. J. (1996). Economic "short-termism": The debate, the unresolved issues, and the implications for management practice and research. Academy of Management Review, 21(3), 825-860.

Le Breton-Miller, L., \& Miller, D. (2006). Why do some family businesses out-compete? Governance, long-term orientations, and sustainable capability. Entrepreneurship Theory and Practice, 30(6), 731-746.

Lee, J. (2006). Family firm performance: Further evidence. Family Business Review, 19(2), 103-114.

Lee, J. (2004). The effects of family ownership and management on firm performance. SAM Advanced Management Journal, 69(4), 46-53.

Mathur, L. K., \& Mathur, I. (2000). An analysis of the wealth effects of green marketing strategies. Journal of Business Research, 50(2), 193-200.

Mathur, L. K., Mathur, I., \& Rangan, N. (1997). The wealth effects associated with a celebrity endorser: The Michael Jordan phenomenon. Journal of Advertising Research, 37, 67-73.

Maury, B. (2006). Family ownership and firm performance: Empirical evidence from Western European corporations. Journal of Corporate Finance, 12(2), 321-341.

McGrath, R., \& Nerkar, A. (2004). Real options reasoning and a new look at the R\&D investment strategies of pharmaceutical firms. Strategic Management Journal, 25(1), 1-21.

Miller, D., \& Breton-Miller, L. (2006). Family governance and firm performance: Agency, stewardship, and capabilities. Family Business Review, 19(1), 73-87.

Miller, D., Le Breton-Miller, I., Lester, R. H., \& Cannella, A. A. (2007). Are family firms really superior performers? Journal of Corporate Finance, 13(5), 829-858.

Minichilli, A., Corbetta, G., \& MacMillan, I. C. (2010). Top management teams in family-controlled companies: 'familiness', 'faultlines', and their impact on financial performance. Journal of Management Studies, 47(2), 205-222.

Mizik, N., \& Jacobson, R. (2003). Trading off between value creation and value appropriation: The financial implications of shifts in strategic emphasis. Journal of Marketing, 67(1), 63-76.

Moores, K. (2009). Paradigms and theory building in the domain of business families. Family Business Review, 22(2), 167-180.

Morck, R., \& Yeung, B. (2003). Agency problems in large family business groups. Entrepreneurship Theory and Practice, 27(4), 367-382.

Morck, R., Stangeland, D., \& Yeung, B. (2000). Conference volume from concentrated corporate ownership, NBER '2000: Inherited wealth, corporate control, and economic growth? Chicago, IL: University of Chicago.

O'Boyle, E. H., Pollack, J. M., \& Rutherford, M. W. (2012). Exploring the relation between family involvement and firms' financial performance: A meta-analysis of main and moderator effects. Journal of Business Venturing, 27(1), 1-18.

Olson, P. D., Zuiker, V. S., Danes, S. M., Stafford, K., Heck, R. K., \& Duncan, K. A. (2003). The impact of the family and the business on family business sustainability. Journal of Business Venturing, 18(5), 639-666.

Rego, L. L., Morgan, N. A., \& Fornell, C. (2013). Reexamining the market share-customer satisfaction relationship. Journal of Marketing, 77(5), 1-20.

Reuber, A. R., \& Fischer, E. (2011). Marketing (in) the family firm. Family Business Review, 24(3), $193-196$.

Roodman, D. (2006). How to do xtabond2: An introduction to difference and system GMM in Stata (Center for Global Development Working Paper No. 103.) Retrieved from Social Science Research Network (SSRN) website: https://papers.ssrn.com/sol3/papers.cfm?abstract_id=982943

Schulze, W. S., Lubatkin, M. H., \& Dino, R. N. (2003). Toward a theory of agency and altruism in family firms. Journal of Business Venturing, 18(4), 473-490. 
Sharma, P., Chrisman, J., \& Chua, J. (1997). Strategic management of the family business: past research and future challenges. Family Business Review, 10(1), 1-35.

Shleifer, A., \& Vishny, R. W. (1986). Large shareholders and corporate control. Journal of Political Economy, 94(3/1), 461-488.

Shleifer, A., \& Vishny, R. W. (1997). A survey of corporate governance. The Journal of Finance, 52(2), 737-783.

Silva, F., \& Majluf, N. (2008). Does family ownership shape performance outcomes? Journal of Business Research, 61(6), 609-614.

Srinivasan, S., \& Hanssens, D. M. (2009). Marketing and firm value: metrics, methods, findings, and future directions. Journal of Marketing Research, 46(3), 293-312.

Srivastava, R. K., Shervani, T. A., \& Fahey, L. (1998). Market-based assets and shareholder value: A framework for analysis. The Journal of Marketing, 62(1), 2-18.

Stein, J. C. (1988). Takeover threats and managerial myopia. The Journal of Political Economy, 96(1), 61-80.

Stein, J. C. (1999). Efficient capital markets, inefficient firms: A model of myopic corporate behavior. The Quarterly Journal of Economics, 104(4), 655-669.

Tharawat Magazine. (2014). The economic impact of family businesses: A compilation of facts. Retrieved from http://www.tharawat-magazine.com/the-economic-impact-of-family-businesses/1961-studying-theeconomic-impact-of-family-businesses-a-compilation-of-facts.html.

Tribo, J. A., Berrone, P., \& Surroca, J. (2007). Do the type and number of block holders influence R\&D investments? New evidence from Spain. Corporate Governance: An International Review, 15(5), 828-842.

Villalonga, B., \& Amit, R. (2006). How do family ownership, control and management affect firm value? Journal of Financial Economics, 80(2), 385-417.

Ward, J. L. (1988). The special role of strategic planning for family businesses. Family Business Review, 1(2), 105117.

Weber, J., Lavelle, L., Lowry, T., Zellner, W., \& Barrett, A. (2003). Family Inc. Business Week, November 10, 100114.

Wooldridge, J. M. (2010). Econometric analysis of cross section and panel data. Cambridge, MA: MIT press.

Yoganarasimhan, H. (2012). Impact of social network structure on content propagation: A study using YouTube data. Quantitative Marketing and Economics, 10(1), 111-150.

Zahra, S. A., \& Sharma, P. (2004). Family business research: A strategic reflection. Family Business Review, 17, 331-346. 